\title{
Neighbourhood-based evidence of tree diversity promotion by beech in an old-growth deciduous- coniferous mixed forest (Eastern Carpathians)
}

\author{
Dan Gafta1 ${ }^{\varpi}$, Annik Schnitzler ${ }^{2}$, Déborah Closset-Kopp³ ${ }^{3}$, Vasile Cristea ${ }^{1}$
}

Gafta D., Schnitzler A., Closset-Kopp D., Cristea V., 2021. Neighbourhood-based evidence of tree diversity promotion by beech in an old-growth deciduous-coniferous mixed forest (Eastern Carpathians). Ann. For. Res. 64(1): 13-30.

Abstract Neighbourhood models are useful tools for understanding the role of positive and negative interactions in maintaining the tree species diversity in mixed forests. Under such a presumption, we aimed at testing several hypotheses concerning the mechanisms of autogenic species coexistence in an old-growth, beech-fir-spruce stand, which is part of the Slătioara forest reserve (Eastern Carpathians). Univariate/bivariate spatial point pattern analyses, the individual tree species-area relationship, the species mingling analysis and generalised linear mixed models of neighbour interference were applied on data concerning the position and allometry of all saplings and trees occurring within a 0.24 ha plot.

The monospecific distribution of either beech or spruce saplings did not support the spatial segregation hypothesis. There was no evidence of conspecific negative distance dependence, as no spatial segregation was detected between the saplings and trees of any species. Within 4 m-neighbourhood, the beech saplings appeared as diversity accumulators, which might be indicative of indirect facilitation (e.g., herd protection hypothesis). At tree stage, none of the three species showed either accumulator or repeller patterns in their neighbourhood with respect to sapling species richness. Signals of positive and negative interspecific association were found in tree-sized beech (at scales of 10 to $20 \mathrm{~m}$ ) and spruce (at scales of 4 to $17 \mathrm{~m}$ ), respectively. The former, highly interspersed pattern is in accordance with the hypothesis of positive complementary effects, whereas the latter, poorly intermingled pattern is probably linked to the unexpected, positive neighbouring effect of spruce trees on the stem growth of their conspecific saplings. Such self-favouring process might be due to a facilitative below-ground mechanism. Conversely, the beech saplings were suppressed through interference from the neighbouring conspecific trees.

The beech appears to be the key promoter of tree species coexistence in the study forest stand, in contrast to the low interspersion of spruce in the overstorey leading to lower local tree diversity.

Keywords: auto-facilitation, beech-fir-spruce mixed forest, diversity accumulator, neighbourhood effect, null models, self-competitor, spatial point pattern, tree species mingling. 
Addresses: ${ }^{1}$ Department of Taxonomy and Ecology, Centre 3B, Babeș-Bolyai University, Romania| ${ }^{2}$ Laboratoire Interdisciplinaire des Environnements Continentaux, Université de Lorraine, Metz, France ${ }^{3}$ Unité Ecologie et Dynamique des Systèmes Anthropisés, Université de Picardie Jules Verne, Amiens, France.

$\vartheta$ Corresponding Author: Dan Gafta (dan.gafta@ubbcluj.ro).

Manuscript received February 8, 2021; revised May 14, 2021; accepted May 26, 2021.

\section{Introduction}

Along with propagule availability and environmental filters, niche-based interactions have been widely considered as the main drivers of species coexistence and community assembly (Wilson 2011, Kraft et al. 2015). In forest communities, a number of mechanisms have been proposed to explain the local scalecoexistence of tree species: different patterns in seed dispersal and persistence (Harms et al. 2001, Wright 2002, Hou et al. 2004, PunchiManage et al. 2015); habitat heterogeneity (Koukoulas \& Blackburn 2005, King et al. 2006, Getzin et al. 2008, Chen et al. 2010, Piao et al. 2013); autogenic alternation (reciprocal replacement) of species between ontogenetic cycles (Fox 1977, Woods 1979); allogenic formation of canopy gaps by natural disturbance (Canham 1988, Poulson \& Platt 1996) and demographic stochasticity (Gravel et al. 2008). Recent studies have suggested that niche structuring is a major determinant of species diversity in temperate mixed forests (Gilbert \& Lechowicz 2004, Laliberté et al. 2009, Zhang et al. 2010). Two different classes of biotic mechanisms mediate coexistence by preventing competitive exclusion (Chesson 2000): equalising mechanisms, which reduce the relative fitness difference between species (e.g., facilitation or symmetric competition) and stabilising mechanisms, which reduce niche overlap (e.g., specialisation or selfinhibition).

The niche-based mechanisms related to spatial processes are especially important for plant species coexistence because they are sessile organisms that interact mainly with their close neighbours. Such interactions may lead to either negative or positive net effects, mainly depending on the balance between asymmetric competition for limiting resources (light, nutrients) and facilitation (nursering), i.e. either resource limitation or diversification (Chi et al. 2015, Bulleri et al. 2016). Other possible mechanisms underlying the negative and positive interactions between neighbouring plants may include shared pests (e.g., pathogens, herbivores) and respectively, shared mutualists - like mycorrhizae and seed dispersers (Punchi-Manage et al. 2015).

In temperate mixed forests composed of more or less shade-tolerant tree species, dominance can easily change from one species to another between consecutive generations (Woods 1984, Arii \& Lechowicz 2002). Negative spatial association between conspecifics by means of reciprocal replacement were reported in mixed deciduous-coniferous forests from different geographic regions (Bândiu 1977, Nakashizuka \& Kohyama 1995, Akashi 1996, Kuninaga et al. 2015). The autogenic coexistence through reciprocal replacement of tree species can originate from various processes like, direct facilitation (e.g., light spectral filtering), intraspecific inhibition (e.g., auto-allelopathy) or indirect facilitation (e.g., 'escape' and 'herd immunity' hypotheses). As a necessary but not sufficient condition, it seems that coexistence requires interspecific differences in light transmissivity through the crowns of adult trees (Cammarano 2011). For instance, fir regenerates better under beech canopy due to the greater transmission of blue and red light (Bândiu 1977, Dobrowolska 1998). On the contrary, the self-inhibition of 
fir saplings through auto-intoxication has been documented in pure silver fir stands (Becker \& Drapier 1984, 1985).

The 'escape hypothesis' or 'conspecific negative density/distance-dependence' (CNDD) assumes that, because the dispersed seed density is typically highest near the parent tree, specialised enemies (pathogens, herbivores) accumulate and reduce seedling establishment near conspecific trees, resulting in lower intraspecific aggregation (Comita et al. 2014). Recent studies brought evidence of CNDD as being an important driver of species coexistence in temperate oldgrowth forests (Getzin et al. 2008, Johnson et al. 2014, Kuang et al. 2017), including mixed coniferous-deciduous forests (Nakashizuka \& Kohyama 1995, Hiura \& Fujiwara 1999, Kotanen 2007, Bai et al. 2012, Piao et al. 2013). The 'herd immunity hypothesis' gives a similar explanation of the reciprocal replacement of trees species but from a different angle: it predicts that high local species diversity confers protection from natural enemies by rendering it more difficult for specialist natural enemies to locate the target plants (Wills et al. 1997). If both the escape and herd immunity theories hold, there should be a tendency toward high spatial mingling of tree species and ultimately, a high local species diversity (Blundell \& Peart 2004, Volkov et al. 2005, Swamy et al. 2011, Pommerening \& Uria-Diez 2017).

The approach based on distance-dependent analyses can be also employed to assess the performance of a focal tree based on the characteristics of its nearest neighbours. Usually, the target tree growth and/or survival is analysed as a function of the size and distance from the neighbours (Wagner \& Radosevich 1998, Canham et al. 2004, Kunstler et al. 2016), but the taxonomic identity of the latter has been shown to be equally important (Uriarte et al. 2004). If the net effect of the nearest neighbours on the focal trees is not null, then spatial structure in local species richness may emerge (Lieberman \& Lieberman 2007). Since positive and negative interspecific interactions can cause local maxima and respectively, minima in species richness, the analysis of individual species-area relationship (ISAR) may reveal the taxonomic identity of the so-called diversity 'accumulators' and respectively, 'repellers' (Wiegand et al. 2009). Finally, the third category includes the socalled 'neutral species', which do not display patterns (peaks or saddles) in neighbourhood species richness and are presumably related to stochastic assorting (Wiegand et al. 2007). Species displaying high-diversity neighbourhoods may indicate a preponderance of positive interspecific interactions or strong CNDD, while species with low-diversity neighbourhoods may indicate dominance of inhibitory effects on heterospecific neighbours or strong conspecific positive densitydependence. As a consequence, the proportion of diversity 'repellers' and 'accumulators' within a community could shed light on the mechanisms ruling coexistence in tree communities (Espinosa et al. 2015).

The 'spatial segregation hypothesis', which involves negative spatial association between heterospecific individuals, can also be related to species coexistence (Pacala \& Levin 1997). Intraspecific aggregation of juveniles (due to limited seed dispersal or gap-based regeneration niche) leads to interspecific segregation, which in turn prevents the exclusion of competitively inferior species (Stoll \& Prati 2001), thereby promoting species diversity. At later life stages, stable coexistence of tree species can be achieved by 'positive complementary effects' that arise owing to great niche differentiation (Cavard et al. 2011, Lasky et al. 2014, Forrester \& Bauhus 2016). Several mechanisms may be responsible for such effects, like reduction in crown interference due to spatial stratification (Pretzsch 2014) or improved nutrient availability by virtue of more efficient exploitation of soil resources (Rothe \& Binkley 2001).

The main goal of this study was to search for spatial dependence and neighbourhood 
patterns across/within tree species and size classes in an old-growth, mixed beech-firspruce forest, in order to test hypotheses about the underlying mechanisms of autogenic species coexistence. We hypothesized that local tree species diversity could be promoted and maintained by: i) facilitative interactions between heterospecific saplings in the shaded understorey; ii) effects of conspecific negative distance-dependence, self-inhibition and positive interspecific interactions between trees and saplings; iii) positive complementarity effects between canopy trees.

Assuming that such deterministic mechanisms of autogenic species coexistence exert stronger effects than negative interspecific interactions in self-regenerating, stable, old-growth mixed forests, we expected to observe (at small spatial scales) patterns of aggregation/segregation or positive/negative association between heterospecific/conspecific individuals, and negative neighbourhood effects of trees on the growth of conspecific saplings. By reference to appropriate null models of spatial point pattern, we analysed: i) the distribution of conspecific saplings for testing the spatial segregation hypothesis; ii) the distribution of saplings of each species with respect to their conspecific/heterospecific trees for testing the reciprocal replacement hypothesis, and iii) the individual tree speciesarea relationship and tree species mingling for testing the diversity accumulator/repeller hypothesis and respectively, the positive complementarity effects. In addition, we estimated the effect of the nearest conspecific/ heterospecific tree size on the height of focal saplings for testing the hypothesis of asymmetric competition.

\section{Materials and Methods}

\section{Study area}

The Codrul Secular Slătioara forest reserve $\left(47^{\circ} 27^{\prime} \mathrm{N} ; 25^{\circ} 37^{\prime} \mathrm{E}\right)$ lies in the Rarău Mountains
(Eastern Carpathians, Romania) between 800 and $1510 \mathrm{~m}$ above sea level (Fig. 1). The climate is temperate-continental with mean annual temperatures between 3.9 and $5.8^{\circ} \mathrm{C}$ and mean annual precipitation ranging from 700 to $810 \mathrm{~mm}$ (Duduman et al. 2014). The forest reserve was created in 1941 and covered an area of 854.3 ha until in 2006, when it was extended to 1064.2 ha. The mixed forest canopy is formed of European beech (Fagus sylvatica), silver-fir (Abies alba) and Norway spruce (Picea abies), except in the upper montane stands (over $1350 \mathrm{~m}$ of elevation) that are beyond the beech altitudinal range.

The investigations were undertaken on a mild $(25 \%)$ north-western slope covered by rendzina soils, at an elevation of about 830 $\mathrm{m}$ a.s.1. By reference to living plants only, the beech was by far the most abundant tree species in both over- and under-storey (67\%), followed by spruce $(24 \%)$ that rarely reached the uppermost level of the forest canopy (Table 1). The fir had a modest share of $9 \%$ and was poorly represented in the understorey, in spite of the fir trees having cumulated the largest basal area and being on average the tallest among the three species (Table 1). In terms of proportion of dead standing individuals in each species population, spruce was ranked first $(22.7 \%)$, followed by fir $(9.8 \%)$ and beech (only $4.8 \%$ ). Overall, the tree population structure was uneven but also heterogeneous throughout the Slătioara forest (Cenuşă et al. 2002), and in particular, the study stand featured a low number of trees in the middle size classes (Schnitzler et al. 2004). According to the forest classification on ecosystemic bases by Doniţă et al. (1990), the study stand can be assigned to the forest ecosystem type 2316 , characterised by highly to moderately productive spruce-beech-fir stands, developed on eu-mesobasic brown or rendzinic soils, well balanced in terms of water supply, featuring a mull-moder humus type and a herbaceous layer of Oxalis-Dentaria-Asperula type. 

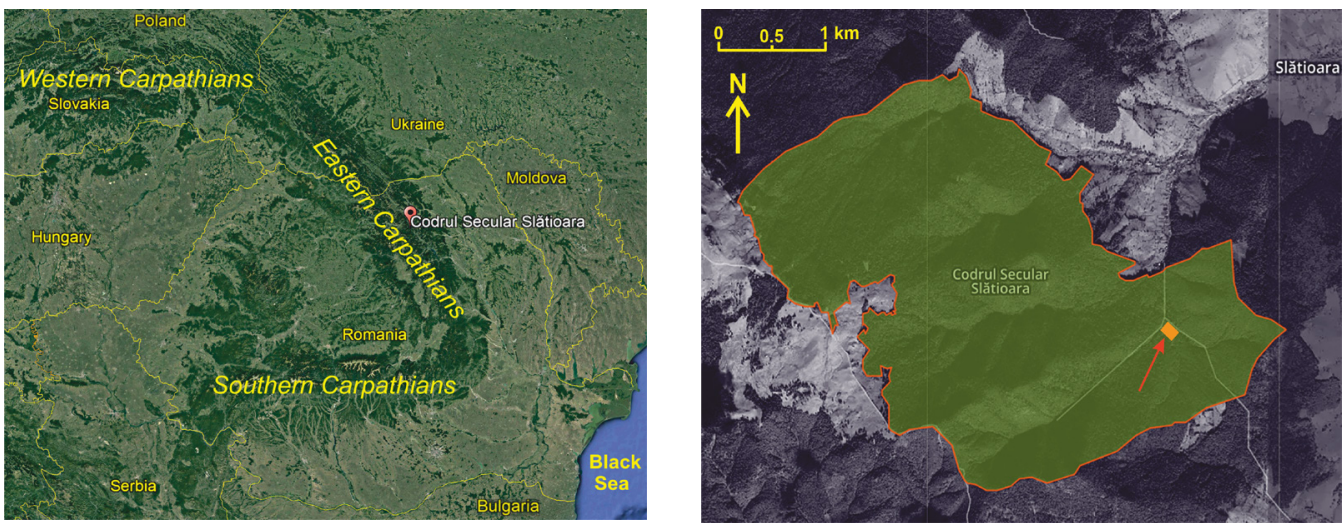

Figure 1 Geographic location of the Codrul Secular Slătioara forest reserve (left) and the approximative placement of the inventoried plot within the protected area (right).

Table 1 Summary statistics of the population size and allometry of the living plants (seedlings excluded) by tree species in the study forest stand.

\begin{tabular}{llccc}
\hline Variable & Statistics & Fir & Beech & Spruce \\
\hline Density (N/ha) & Sum & 154 & 1154 & 413 \\
Basal area (m²/ha) & Sum & 31.9 & 17.8 & 8.2 \\
& Range (min - max) & $3.2-114.5$ & $3.2-79.3$ & $3.2-116.8$ \\
Diameter (cm) & Median & 28.1 & 4.8 & 6.3 \\
& Mean \pm SD & $42.9 \pm 38.2$ & $13.5 \pm 16.9$ & $10.3 \pm 17.4$ \\
& Range (min - max) & $1.0-48.0$ & $0.1-38.0$ & $0.9-51.5$ \\
Height (m) & Median & 12.5 & 3.7 & 2.9 \\
& Mean \pm SD & $18.0 \pm 16.9$ & $6.4 \pm 8.3$ & $4.4 \pm 7.2$ \\
\hline
\end{tabular}

\section{Data collection}

The field work was carried out in 2001 within a $40 \times 60 \mathrm{~m}$ rectangular plot circumscribed to a relatively homogeneous area in terms of site conditions and stand physiognomy, and located (at that time) within the buffer zone of the forest reserve. The long sides of the plot were placed along the steepest slope path, i.e. perpendicular to the contour lines.

The height and Cartesian coordinates (with respect to one plot corner) of all living and dead standing tree species individuals (except seedlings) were measured using a clinometer and respectively, a tape ruler. In addition, the stem girth at breast height (1.30 $\mathrm{m})$ was measured on all individuals that were at least $1.50 \mathrm{~m}$ tall. Two size classes were distinguished based on trunk thickness, i.e. individuals displaying a stem girth of at least $10 \mathrm{~cm}(\mathrm{DBH} \geq 3.2 \mathrm{~cm})$ were considered trees, whereas all others were included in the category of saplings.

\section{Data analysis}

We used point pattern analyses of fully mapped plant locations to explore the 
univariate and bivariate spatial patterns in the distribution of individuals (Wiegand \& Moloney 2014). The univariate analysis was employed on conspecific saplings to test the spatial segregation hypothesis. The bivariate analysis was performed on saplings relative to their conspecific or heterospecific trees, in order to test the auto-inhibition or the CNDD hypothesis, respectively. In the spatial point pattern analysis we used the pair-correlation function $\mathrm{g}(r)$, which is a second-order statistic that employs the probability of observing a pair of points separated by a distance $r$ (Illian et al. 2008). We computed the $\mathrm{g}(r)$ distributions applying a lag distance of $0.5 \mathrm{~m}$ over a maximum range of $20 \mathrm{~m}$ (i.e., half the minimum side of the plot).

Neighbourhood effects on tree species richness and mingling were tested using species-by-all-species analyses, which integrate across all species around a focal species and are more likely to detect effects of biotic interactions than species-by-species analyses (Punchi-Manage et al. 2015). The individual species-area relationship (ISAR) estimates the change in species richness with increasing area and distance from heterospecific neighbours to target species individuals by integrating the spatial structure of individuals (Wiegand et al. 2007, Wiegand \& Moloney 2014). Depending on the occurrence or absence of local minima or maxima of species richness with respect to a null model, the ISAR approach allows the grouping of target species in (diversity) accumulators, repellers and neutrals (Wiegand et al. 2007). The mingling index $(\mathrm{M})$ is a measure of interspersion of trees of different species and is defined as the proportion of the $n$ nearest neighbours that do not belong to the same species as the reference tree (Pommerening \& Grabarnik 2019). If the nearest neighbours and the target tree always share the same species, then $\mathrm{M}=0$ (minimum intermingling), else if all neighbours are always taxonomically different from the target tree species, then $\mathrm{M}=1$ (maximum intermingling).

The significance of all previously mentioned distributions or statistics (i.e., g(r), ISAR and M) was assessed through simulations of (density constrained) random distribution of trees or saplings, in order to account for possible (undesirable) effects of habitat patchiness, stand history and dispersal limitation that can induce non-random patterns in the spatial disposal of individuals, irrespective of biotic interactions (Wiegand et al. 2007, Rayburn \& Wiegand 2012, Baddeley et al. 2014, Espinosa et al. 2015, Tsai et al. 2015). To account for large variation in tree density within the plot, we only used inhomogeneous Poisson processes along with the Ripley's isotropic edge correction in simulating the null models of spatial independence. The tree or sapling density throughout the plot was computed nonparametrically by employing the Epanechnikov kernel estimators of the intensity function with the option for Jones-Diggle improved edge correction (Diggle 2010, Wiegand \& Moloney 2014).

In the univariate $\mathrm{g}(r)$ analysis, the null hypothesis was simulated through the random (but density-constrained) spatial disposal of conspecific saplings (Baddeley et al. 2015). The null model used for testing the significance of the bivariate $\mathrm{g}(r)$ and ISAR was the independence of the two spatial point pattern types (across size classes and/ or species), i.e. no spatial interaction between them (Baddeley et al. 2015). The simulations corresponding to the last null model were performed by randomly reallocating the spatial position of neighbouring saplings with punctual probabilities derived from the estimated density (intensity), while keeping the spatial arrangement of saplings or trees of focal species fixed (Wiegand \& Moloney 2014). Finally, the significance of the observed $M$ index values was tested through the null model of random labelling (independence between marks and points), that is by shuffling the taxonomic identity of trees while keeping the number and spatial position of trees in each species constant (Baddeley et al. 2015). 
Two-sided, pointwise envelopes for the observed $\mathrm{g}(r)$, ISAR and $\mathrm{M}$ distributions were generated from 999 Monte Carlo simulations and an overall goodness-of-fit (GoF) test was performed (Loosmore \& Ford 2006).

To describe the neighbourhood interference of trees on the target sapling, we employed the Weiner's (1984) measure $(W)$ :

$$
W=\sum_{i=1}^{n} \frac{s_{i}}{d_{i}^{2}}
$$

where $n$ is the total number of neighbours, $d_{i}$ is the distance from the target sapling to the $i$-th neighbouring tree and $s_{i}$ is the size of the $i$-th neighbouring tree. The size of trees was roughly estimated by reference to the volume of a cone whose dimensions were equal to the tree's diameter and height. We calculated the $W$ values for each neighbouring tree species separately by considering only the nearest conspecific and heterospecific trees $(n=1)$. In the rare cases in which the focal sapling was taller than one of the neighbouring tree, the corresponding $W$ measure was equalled to zero.

Generalised linear mixed models (GLMMs) were employed to analyse the sapling height in each species as a function of the interference from each of the nearest neighbouring, conspecific and heterospecific trees, while controlling the influence of spatial autocorrelation (Bolker et al. 2009). The latter was handled through a residual random component with an anisotropic power covariance structure, which provided the best fitting results and could account for possible differences induced by the terrain slope. The negative binomial distribution along with a loglink was employed in GLMMs for adjusting the conditional probability distribution of the response variable (i.e., sapling height). The goodness-of-fit of each model was assessed through the generalised chi-square divided by the degrees of freedom (Gen. Chi-sq/DF).

Both living and dead individuals were considered in $\mathrm{g}(r)$, ISAR and species mingling analyses, as the allometric measures were not involved in computations. On the contrary, only living individuals were considered in the neighbourhood interference analysis through GLMMs.

Because the total number of fir saplings was too low (seven living and one dead), the results of analyses involving their spatial point pattern exclusively or their allometric characteristics were either incomplete or biased, and hence were not reported.

All numerical analyses were performed in $\mathrm{R}$ v3.6.3 environment ( $R$ Core Team 2020) using the packages 'spatstat' (Baddeley et al. 2020), 'idar' (de la Cruz 2019) and 'spatialsegregation' (Rajala 2019), except for GLMMs that were run in SAS/STAT 9.4 (SAS Institute Inc. 2014).

\section{Results}

A weak but significant aggregation of beech saplings was detected only at $1 \mathrm{~m}$-scale (Fig. 2a). At larger scales, the distribution of beech saplings was not significantly different from the null model. The spruce saplings were randomly distributed at all scales (Fig. 2b).

Saplings of any species did not show significant spatial patterns with respect to their conspecific (Fig. 3a-c) or heterospecific trees (Fig. 3d-i).

Within 4 m-neighbourhood of beech saplings, a higher taxonomic sapling richness than expected under the null hypothesis was detected (Fig. 4a). Instead, the individual species-area relationships (ISARs) corresponding to the fir and spruce saplings were not significantly different from their simulated counterparts (Fig. 4b-c). When the trees and saplings were considered as focal and respectively, target individuals, the ISARs built for the three species (beech, fir and spruce) were all fully embedded within the corresponding simulation envelopes (Fig. 4d-f).

A significant, positive, spatial association between trees species was detected at scales larger than $10 \mathrm{~m}$ around the beech trees, as indicated 
by the large observed values of the mingling index compared to the simulated values (Fig. 5a). An opposite pattern was detected within a radius of 4 to $17 \mathrm{~m}$ around the spruce trees, that is a significant, negative, spatial association between the three species (Fig. 5b). Finally, no significant spatial association between the three species was observed in the neighbourhood of fir trees (Fig. 5c).

The height of beech saplings was significantly, negatively affected by the interference from the nearest conspecific tree, whereas the negative effects of the nearest fir and spruce tree were not significant (Table 2). On the contrary, the nearest spruce tree displayed a significant, positive effect on the height of conspecific saplings (Table 2). The nearest beech exerted a nonsignificant, negative effect on the spruce sapling height, whereas the neighbourhood effect of the nearest fir tree was almost null (Table 2).

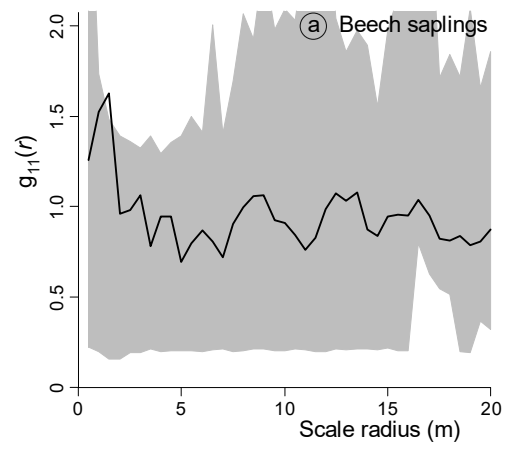

Table 2 Standardised coefficients associated with the (fixed) interference effects $(W)$ of the nearest neighbour beech, fir and spruce tree on the height of beech $(n=156)$ and spruce $(n=37)$ saplings. The goodnessof-fit of each GLMM is reported in the last row

\begin{tabular}{lll}
\hline \multicolumn{1}{c}{ Response } & \multicolumn{2}{c}{ Sapling height } \\
\cline { 2 - 3 } Predictors & Beech & Spruce \\
\hline$W$ (beech trees) & $-1.282^{* *}$ & $-0.372^{\mathrm{ns}}$ \\
$W$ (fir trees) & $-0.522^{\mathrm{ns}}$ & $-0.006^{\mathrm{ns}}$ \\
$W$ (spruce trees) & $0.084^{\mathrm{ns}}$ & $0.494^{*}$ \\
Intercept & $0.992^{2}$ & 0.446 \\
\hline Gen. Chi-sq/DF & 1.00 & 1.10 \\
\hline
\end{tabular}

** $0.001<p<0.01 ; * 0.01<p<0.05$; ${ }^{\text {ns }}$ non-significant

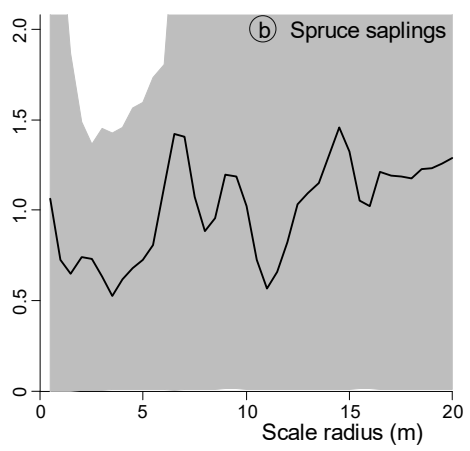

Figure 2 Empirical distribution of the univariate pair-correlation function $\mathrm{g} 11(r)$ associated with the spatial distribution of beech (a) and spruce (b) saplings. The grey area represents a $99.9 \%$ simulation envelope based on a heterogeneous Poisson null model. 

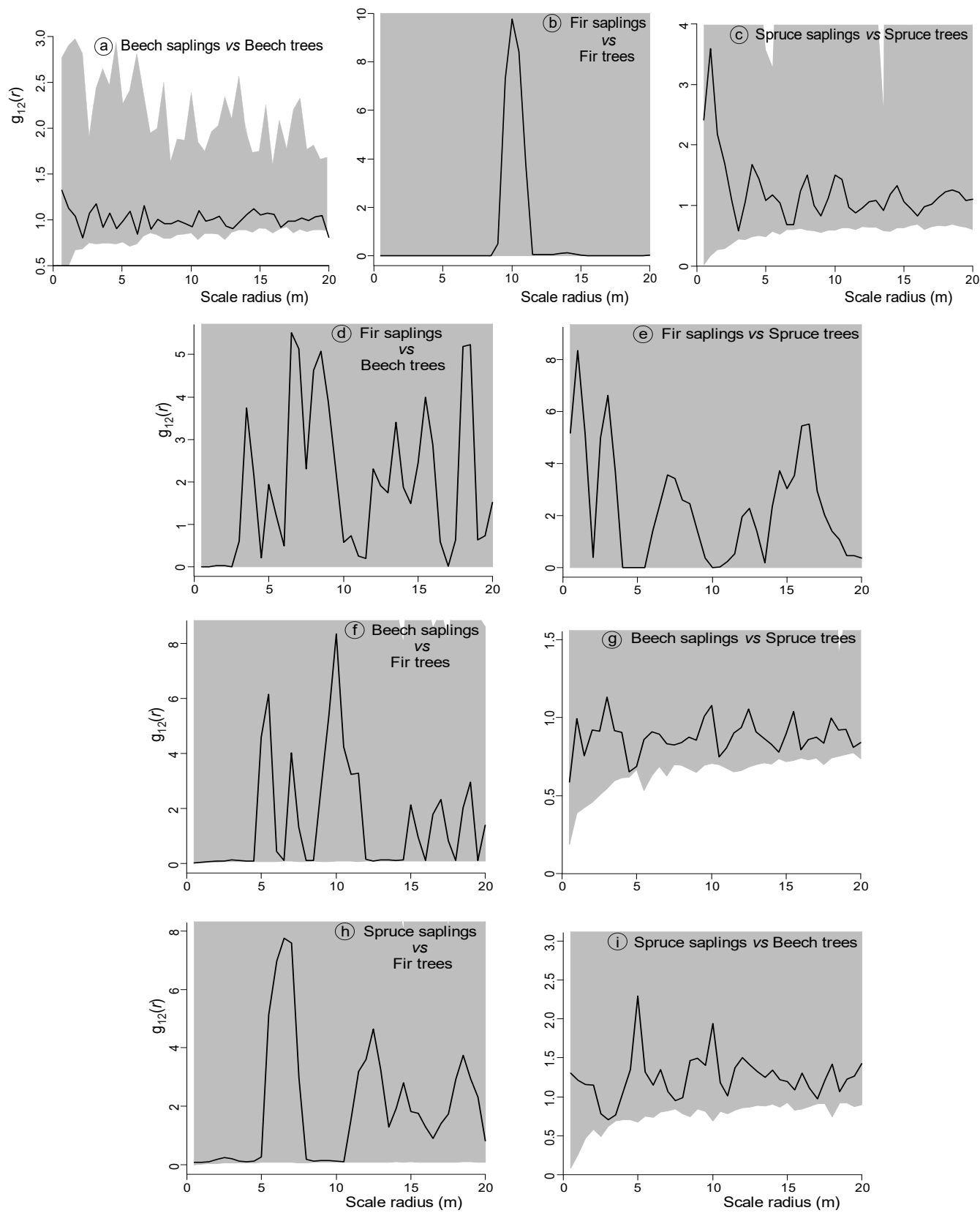

Figure 3 Empirical distribution of the bivariate pair-correlation function $\mathrm{g} 12(r)$ associated with the spatial distribution of beech, fir and spruce saplings with respect to their conspecific (a-c) and respectively, heterospecific (d-i) trees. Simulation envelopes (in grey) as in Fig. 1. 

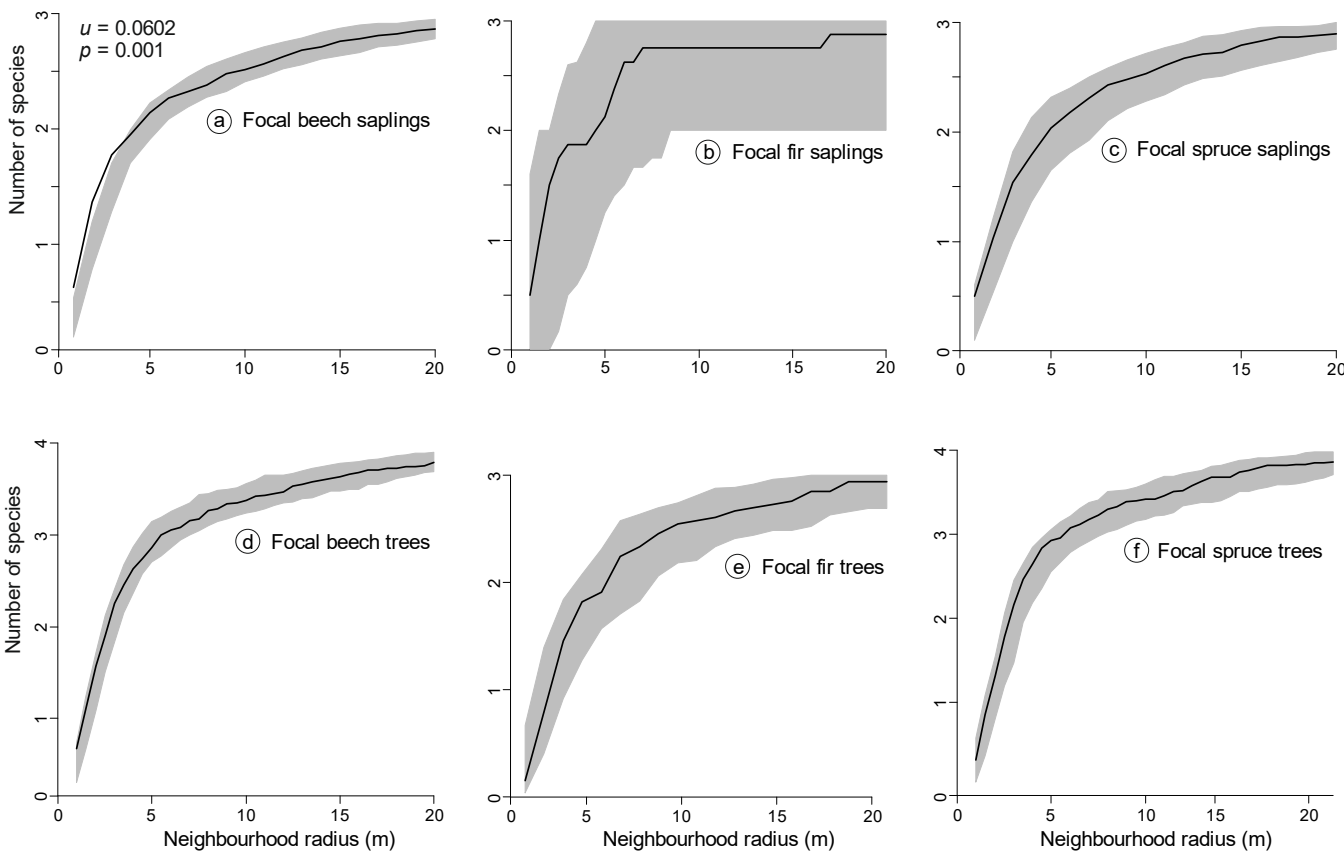

Figure 4 Observed individual species-area relationships (ISARs) built within-saplings (a-c) and acrosssize classes (d-f) by using every possible focal species. The number of species on the $\mathrm{Y}$ axis includes the focal species (size class). The statistics $(u)$ of the goodness-of-fit test is displayed for significance validation. Simulation envelopes (in grey) as in Fig. 1.
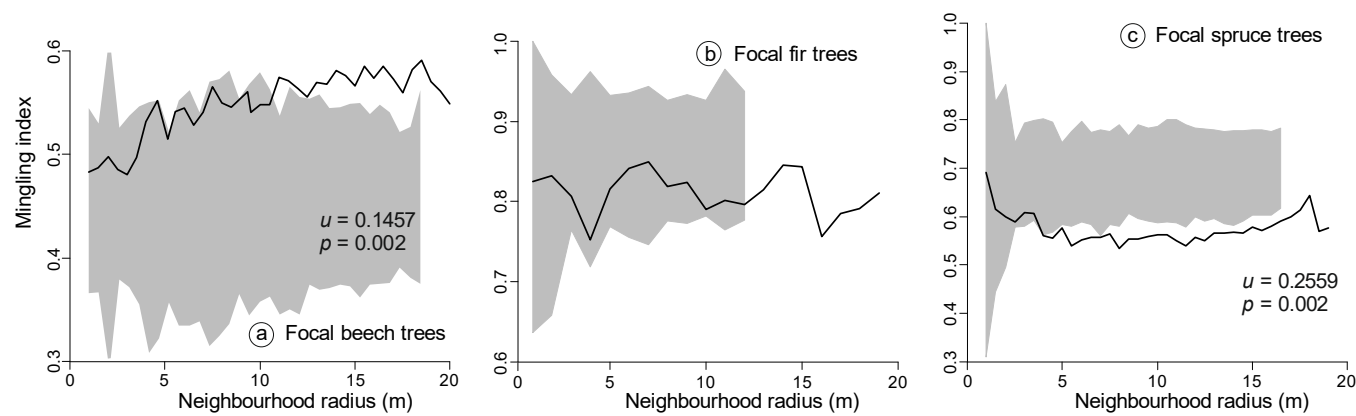

Figure 5 Empirical distribution of the mingling index (M) by neighbourhood radius built for trees only by using the beech (a), fir (b) and spruce (c) as focal species. The statistics $(u)$ of the goodness-of-fit test is displayed for significance validation. The grey area represents a $99.9 \%$ simulation envelope based on the null model of random labelling. The envelopes are truncated at large scales because of the null variance (equal observed and simulated values of the mingling index). 


\section{Discussion}

The monospecific distribution of either beech or spruce saplings did not support the spatial segregation hypothesis, which was found to explain the tree species coexistence in other temperate mixed forests (e.g., Wang et al. 2010, Zhou et al. 2019). Our results are, to some extent, unexpected as both beech and spruce are known to regenerate regularly within canopy gaps (Nagel et al. 2006, Paluch et al. 2019). Beech is a typical gap-filler capable of rapid crown enlargement (Nagel et al. 2010, Janík et al. 2016), whereas spruce is an early and competitive coloniser of canopy openings (Jonášová \& Prach 2004).

We did not find evidence of conspecific negative distance/density dependence (CNDD) as no spatial segregation was detected between saplings and trees of any species. However, Janík et al. (2014) and Petrițan et al. (2015) reported spatial segregation between juvenile and mature beech individuals in old-growth beech-fir forests in western and southern Carpathians, respectively. Likewise, Kuninaga et al. (2015) and Ramage \& Mangana (2017) found evidence of CNDD in Fagus crenata growing in mixed conifer-hardwood forests and respectively, in Fagus grandifolia-dominated, mixed hardwoods. Unfortunately, we could not test for CNDD in fir distribution because of the low number of saplings. Many studies reported the decline of fir populations in mixed stands due to poor seedling recruitment and sapling survival (Diaci et al. 2011, Szwagrzyk et al. 2012, Paluch \& Jastrzębski 2013, Janík et al. 2014, Keren et al. 2014, Parobeková et al. 2018). It seems that not plant-plant interactions are responsible for the regression of fir in mixed stands, but rather a series of other factors among which high accumulation of beech litter (Simon et al. 2011, Janík et al. 2014) and damage by ungulates (Vrška et al. 2009, Klopcic et al. 2010). However, none of these factors seemed to have been acting in the study forest area.
In spite of the well-documented process of reciprocal replacement between beech and fir in mixed forests (Bândiu 1977, Heiri et al. 2009, Vrška et al. 2009, Diaci et al. 2010, Nagel et al. 2010), we did not observe advance regeneration of beech/fir saplings in the neighbourhood of fir/beech trees, which is in accordance with the findings from southern Carpathians (Petrițan et al. 2015). Similar independent spatial distributions between trees and saplings were also revealed at the other two pairs of species: spruce/beech and fir/spruce. Possibly, the demographic heterogeneity and stochasticity may have distorted the ecological response at species level (Hurtt \& Pacala 1995) and may have diluted the spatial patterns in tree species distribution making them weak or undetectable (Gravel et al. 2008). On the other hand, a number of studies documented the positive effects of beech trees on fir regeneration (Dobrowolska \& Veblen 2008, Vrška et al. 2009, Paluch et al. 2016, Paluch et al. 2019).

At sapling stage, only beech displayed significant diversity patterns in its neighbourhood. The apparent role of diversity accumulator of beech saplings cannot be attributable to segregation as such a pattern was not revealed in the distribution of beech recruits. Higher than expected tree species richness in the neighbourhood of beech saplings is in accordance with the positive, although weak, correlations between seedling densities in the beech-fir and beech-spruce mixtures, as reported by Paluch et al. (2019), and might be indicative of net positive interactions or favourable microsites (e.g., gaps) for multiple species regeneration (Wiegand et al. 2007, Espinosa et al. 2015). Due to their relatively small size, it is unlikely that the beech saplings have acted as nurse plants (direct facilitation) with respect to fir and spruce saplings, but some sort of indirect facilitation cannot be excluded. For instance, a plausible explanation could be the herd protection (immunity) theory, i.e. enhanced survival linked to a reduced risk 
of transmission of species-specific pests and pathogens because of the reduced intraspecific density in more diverse assemblages (Peters 2003, Comita et al. 2010).

At tree stage, none of the three species showed either accumulator or repeller patterns in their neighbourhood with respect to sapling species richness. The fact that beech trees do not act as diversity accumulators, like their juveniles, may be caused by the shift in habitat preferences during their ontogenetic development (e.g., large individuals require more resources and are more competitive) and/ or by the different environmental conditions under which the recruitment of trees and saplings occurred (Espinosa et al. 2015). The predominance of neutral diversity patterns in the ISAR analyses points to several possible explanations: existence of environmental filters, i.e. species responding to some kind of environmental heterogeneity (Espinosa et al. 2015); contrasting interactions that average each other out, i.e. null balance of positive and negative interactions (Wiegand et al. 2007, Punchi-Manage et al. 2015); demographic stochasticity due to local disturbance, like those produced by herbivores, pathogens or weather extremes (Wiegand et al. 2007, Gravel et al. 2008). Various authors claimed that, in accordance with the neutral theory (no species interactions), the ecological drift, dispersal limitation and speciation alone can explain the maintenance of tree diversity at local scales, independent of species functional traits (Chave et al. 2002, Hubbell 2006).

Signals of positive and negative interspecific association were found in tree-sized beech and spruce, respectively. The relatively high values of mingling index observed in overstorey beech trees is very likely linked to the status of diversity accumulator revealed in beech saplings. Niche complementarity in root foraging, shade-tolerance, leaf persistence and crown growth architecture may also explain the positive association between beech and the two conifer species in the forest canopy.
Bolte et al. (2013) demonstrated that beech can adopt a flexible root foraging strategy to access soil resources less exploited by spruce, which instead maintains a conservative strategy by keeping a shallow vertical fine root distribution. Such positive complementary effects are partly responsible for the tendency of large trees towards high species mingling, as revealed in several mixed forests across Europe (Pommerening \& Uria-Diez 2017). Nevertheless, we found evidence of avoidance effects in spruce trees due to negative association patterns with respect to the other two species. Several mechanisms may have led to such a poor species interspersion. First, the spruce trees displayed a positive effect on the growth of their conspecific saplings (see the next paragraph). Second, the spruce roots and litter deteriorate the edaphic conditions under which the beech and fir saplings could grow sustainably, i.e. by water and base cation depletion, and raw humus accumulation from and respectively, in the topsoil (Thelin et al. 2002, Paluch \& Gruba 2012, Paluch et al. 2016). Third, despite being less shade-tolerant, spruce possesses some eco-physiological traits that translate in competitive advantages with respect to beech and fir: priority effects gained by the early colonisation of canopy openings (Jonášová \& Prach 2004); best establishment on thick humus layers and coarse woody debris (Szewczyk \& Szwagrzyk 1996, Orman \& Szewczyk 2015); highest rates of height growth (Stăncioiu \& O’Hara 2006).

Only neutral neighbouring effects of trees on the vertical growth of heterospecific saplings were detected in the study stand. On the contrary, significant interactions were revealed between saplings and their nearest parent trees. Like other studies performed in similar mixed forests from central Europe (Bosela et al. 2015, Mina et al. 2018), we observed a suppression in vertical growth of beech saplings in the neighbourhood of conspecific trees. Many studies demonstrated the low self-tolerance of beech (being a strong self- 
competitor for both above-ground and belowground resources) and its severe intraspecific asymmetric competition due to high lateral expansion (Pretzsch 2014, Pretzsch \& Schutze 2016). Besides, beech performs better when growing in mixtures with conifers thanks to reduced intraspecific competition (Bosela et al. 2015, Pretzsch et al. 2010, Mina et al. 2018). On the other side, the unexpected positive effect (instead of interference) of the nearest spruce trees on conspecific saplings could only arise by the greater benefit from parent nursing than the energetic loss due to the asymmetric intraspecific competition. A possible explanation for this self-favouring process could be a facilitative below-ground mechanism, like mutualist soil organisms (e.g., mycorrhizae) that enhance the growth of saplings (Das et al. 2008, Bennett et al. 2017). As mentioned above, such a process may be also responsible for the observed negative spatial association between spruce and the other two species in the tree-size class. The detected auto-facilitation is not necessary in contradiction with the findings reported from the same forest reserve by Duduman et al. (2010), who revealed an opposite effect (interference) on spruce saplings but in terms of their radial growth and considering neighbouring trees of any species. A similar example of auto-facilitation was documented in hemlock trees (Tsuga canadensis) growing in mixed coniferous-deciduous forests in eastern North America (Woods 1984, Catovsky \& Bazzaz 2002).

\section{Limitations and concluding remarks}

Our findings are circumscribed to a (relatively small) extent of 0.24 ha and the distance range of $20 \mathrm{~m}$ (i.e., half of the smallest side of the plot), which might have prevented the detection of spatial patterns beyond that scale, namely signals of interactions between the large trees. Also, the spatial-related patterns that we attributed to biotic interactions could have been induced by habitat microheterogeneity and/or small-scale disturbance, if the latter two factors had acted at the same spatial scales. The ecological response of tree species revealed in this study are only valid in the range of submontane-lower montane belt (800-1200 m) where the climatic conditions are optimal for the growth of beech and fir. Therefore, our findings should be further validated through replicated studies in similar old-growth, (sub) montane mixed forests.

Both as juvenile and adult, the beech seems to be the main player in the equalising and stabilising mechanisms of coexistence and diversity maintenance in the study forest stand. The dominant role of beech in mixture with fir and spruce is also sustained by the unbalanced pair-wise competitive interactions, since the negative effects of beech size-symmetric competition on the growth of fir and spruce is much stronger than the effect of fir and spruce size-symmetric competition on beech growth (Mina et al. 2018). Conversely, the low intermingling of spruce in the overstorey leads to lower local tree diversity. This poor interspersion is supported by the segregated regeneration niche of spruce (e.g., on deadwood) relative to beech and fir (Šebková et al. 2012, Orman \& Szewczyk 2015). The fir seems to occupy an intermediate rank between beech and spruce in terms of its contribution to maintaining the local tree diversity, but this outcome might be partly influenced by the low numeric share of fir, given the strong dependency of association strength on abundance (Vázquez et al. 2007). Based on similar processes observed in many similar forest stands from western Carpathians (Paluch et al. 2019), we suppose that strong reduction in stand density due to intensive exploitations prior to reserve foundation has promoted the establishment of spruce regeneration (even at the lower limit of its altitudinal range) and has decreased the recruitment of fir saplings. 


\section{References}

Akashi N., 1996. The spatial pattern and canopyunderstory association of trees in a cool temperate, mixed forest in western Japan. Ecological Research 11: 311-319. https://doi.org/10.1007/BF02347788

Arii K., Lechowicz M.J., 2002. The influence of overstory trees and abiotic factors on the sapling community in an old-growth Fagus-Acer forest. Ecoscience 9: 386-396. https://doi.org/10.1080/11956860.2002.11682726

Baddeley A., Diggle P.J., Hardegen A., Lawrence T., Milne R.K., Nair G., 2014. On tests of spatial pattern based on simulation envelopes. Ecological Monographs 84: 477-489. https://doi.org/10.1890/13-2042.1

Baddeley A., Rubak E., Turner R., 2015. Spatial point patterns: methodology and applications with $\mathrm{R}$. Chapman and Hall/CRC Press, Boca Raton.

Baddeley A., Rubak E., Turner R., 2020. Spatial point pattern analysis, model-fitting, simulation, tests. $\mathrm{R}$ package 'spatstat' v1.64-1. https://cran.r-project.org/ web/packages/spatstat/spatstat.pdf

Bai X., Queenborough S.A., Wang X., Zhang J., Li B., Yuan Z., Xing D., Lin F., Ye J., Hao Z., 2012. Effects of local biotic neighbors and habitat heterogeneity on tree and shrub seedling survival in an old-growth temperate forest. Oecologia 170: 755-765. https://doi. org/10.1007/s00442-012-2348-2

Bândiu C., 1977. Lumina ca factor stabilizator al compoziției ecosistemelor de amestec de brad cu fag. In: Preda V. (ed.), Pădurea și spațiile verzi în actualitate şi perspectivă. Academia RSR, Cluj-Napoca, pp. 73-82.

Becker M., Drapier J., 1984. Rôle de l'allélopathie dans les difficultés de régénération du sapin (Abies alba Mill.). I Propriétés phytotoxiques des hydrosolubles d'aiguilles de sapin. Acta Oecologica 5: 347-356.

Becker M., Drapier J., 1985. Rôle de l'allélopathie dans les difficultés de régénération du sapin (Abies alba Mill.). II Étude des lessivats naturels de feuillage, de litière et d'humus. Acta Oecologica 6: 31-40.

Bennett J.A., Maherali H., Reinhart K.O., Lekberg Y., Hart M.M., Klironomos J., 2017. Plant-soil feedbacks and mycorrhizal type influence temperate forest population dynamics. Science 355: 181-184. https://doi. org/10.1126/science.aai8212

Blundell A.G., Peart D.R., 2004. Density-dependent population dynamics of a dominant rain forest canopy tree. Ecology 85: 704-715. https://doi.org/10.1890/014101

Bolker B.M., Brooks M.E., Clark C.J., Geange S.W., Poulsen J.R., Stevens M.H.H., White J.S.S., 2009. Generalized linear mixed models: a practical guide for ecology and evolution. Trends in Ecology and Evolution 24: 127-135. https://doi.org/10.1016/j.tree.2008.10.008

Bolte A., Kampf F., Hilbrig L., 2013. Space sequestration below ground in old-growth spruce-beech forests signs for facilitation? Frontiers in Plant Science 4: 322. https://doi.org/10.3389/fpls.2013.00322
Bosela M., Tobin B., Seben V., Petras R., Larocque G.R., 2015. Different mixtures of Norway spruce, silver fir, and European beech modify competitive interactions in central European mature mixed forests. Canadian Journal of Forest Research 45: 1577-1586. https://doi. org/10.1139/cjfr-2015-0219

Bulleri F., Bruno J., Silliman B.R., Stachowicz J.J., 2016. Facilitation and the niche: implications for coexistence, range shifts, and ecosystem functioning. Functional Ecology 30: 70-78. https://doi.org/10.1111/13652435.12528

Cammarano M., 2011. Co-dominance and succession in forest dynamics: the role of interspecific differences in crown transmissivity. Journal of Theoretical Biology 285: 46-57. https://doi.org/10.1016/j.jtbi.2011.06.031

Canham C.D., 1988. Growth and canopy architecture of shade-tolerant trees: the response of Acer saccharum and Fagus grandifolia to canopy gaps. Ecology 69: 786-795. https://doi.org/10.2307/1941027

Canham C.D., Le Page P.T., Dave C.K., 2004. A neighborhood analysis of canopy tree competition: effects of shading versus crowding. Canadian Journal of Forest Research 34: 778-787. https://doi.org/10.1139/ x03-232

Catovsky S., Bazzaz F.A., 2002. Feedbacks between canopy composition and seedling regeneration in mixed conifer broad-leaved forests. Oikos 98: 403-420. https://doi.org/10.1034/j.1600-0706.2002.980305.x

Cavard X., Bergeron Y., Chen H.Y.H., Pare D., Laganiere J., Brassard B., 2011. Competition and facilitation between tree species change with stand development. Oikos 120: 1683-1695. https://doi.org/10.1111/j.16000706.2011.19294.x

Cenușă R., Popa C., Teodosiu M., 2002. Cercetări privind relaţia structură-funcţie şi evoluţia ecosistemelor forestiere naturale din nordul ţării. Analele ICAS 45: 9-19.

Chave J., Muller-Landau H.C., Levin S.A., 2002. Comparing classical community models: theoretical consequences for patterns of diversity. American Naturalist 159: 1-23. https://doi.org/10.1086/324112

Chen L., Mi X.C., Comita L.S., Zhang L.W., Ren H.B., Ma K.P., 2010. Community-level consequences of density dependence and habitat heterogeneity in a subtropical broad-leaved forest. Ecology Letters 13: 695-704. https://doi.org/10.1111/j.1461-0248.2010.01468.x

Chesson P., 2000. Mechanisms of maintenance of species diversity. Annual Review of Ecology and Systematics 31: 343-366.

Chi X., Tang Z., Xie Z., Guo Q., Zhang M., Ge J., Xiong G., Fang J., 2015. Effects of size, neighbors, and site condition on tree growth in a subtropical evergreen and deciduous broadleaved mixed forest, China. Ecology and Evolution 5: 5149-5161. https://doi.org/10.1002/ ece3.1665

Comita L.S., Muller-Landau H.C., Aguilar S., Hubbell S.P., 2010. Asymmetric density dependence shapes species abundances in a tropical tree community. Science 329 : 
330-332. https://doi.org/10.1126/science.1190772

Comita L.S., Queenborough S.A., Murphy S.J., Eck J.L., Xu K.Y., Krishnadas M., Beckman N., Zhu Y., 2014. Testing predictions of the Janzen-Connell hypothesis: a meta-analysis of experimental evidence for distance- and density-dependent seed and seedling survival. Journal of Ecology 102: 845-856. https://doi. org/10.1111/1365-2745.12232

Das A.J., Battles J.J., van Mantgem P.J., Stephenson N.L., 2008. Spatial elements of mortality risk in oldgrowth forests. Ecology 89: 1744-1756. https://doi. org/10.1890/07-0524.1

de la Cruz M., 2020. Individual diversity-area relationships. R package 'idar' v1.1. https://cran.r-project.org/web/ packages/idar/idar.pdf

Diaci J., Rozenbergar D., Anic I., Mikac S., Saniga M., Kucbel S., Visnjic C., Ballian D., 2011. Structural dynamics and synchronous silver fir decline in mixed old-growth mountain forests in Eastern and Southeastern Europe. Forestry 84: 479-491. https://doi. org/10.1093/forestry/cpr030

Diaci J., Rozenbergar D., Boncina A., 2010. Stand dynamics of Dinaric old-growth forest in Slovenia: are indirect human influences relevant? Plant Biosystems 144: 194201. https://doi.org/10.1080/11263500903560785

Diggle P.J., 2010. Nonparametric methods. In: Gelfand A.E., Diggle P.J., Fuentes M., Guttorp P. (eds.), Handbook of spatial statistics. CRC Press, Boca Raton, pp. 299-316.

Dobrowolska D, 1998. Structure of silver fir (Abies alba Mill.) natural regeneration in the 'Jata' reserve in Poland. Forest Ecology and Management 110: 237-247. https://doi.org/10.1016/S0378-1127(98)00286-2

Dobrowolska D., Veblen T.T., 2008. Treefall-gap structure and regeneration in mixed Abies alba stands in central Poland. Forest Ecology and Management 255: 34-69. https://doi.org/10.1016/j.foreco.2008.02.025

Doniță N., Chiriță C., Stănescu V. (eds.), 1990. Tipuri de ecosisteme forestiere din România. Centrul de Material Didactic și Propagandă Agricolă, București.

Duduman G., Roibu C.C., Duduman M.L., MironOnciul M., 2010. The influence of competition and dimensional-spatial characteristics of trees on their radial growth in old-growth Slătioara forest, Romania. AES Bioflux 2: 215-230.

Duduman G., Tomescu C., Drăgoi M., Palaghianu C., 2014. Variabilitatea dimensională a arborilor şi diversitatea florei vasculare în amestecuri de răşinoase cu fag din rezervaţia Codrul secular Slătioara. Bucovina Forestieră 14: 135-147.

Espinosa C., Cruz M., Jara-Guerrero A., Gusmán E., Escudero A., 2015. The effects of individual tree species on species diversity in a tropical dry forest change throughout ontogeny. Ecography 39: 329-337. https://doi.org/10.1111/ecog.01328

Forrester D.I., Bauhus J., 2016. A review of processes behind diversity-productivity relationships in forests. Current Forestry Reports 2: 45-61. https://doi. org/10.1007/s40725-016-0031-2

Fox J.F., 1977. Alternation and coexistence of tree species. American Naturalist 111: 69-89. https://doi. org/10.1086/283138

Getzin S., Wiegand T., Wiegand K., He F.L., 2008. Heterogeneity influences spatial patterns and demographics in forest stands. Journal of Ecology 96: $\quad 807-820$. https://doi.org/10.1111/j.13652745.2008.01377.x

Gilbert B., Lechowicz M.J., 2004. Neutrality, niches, and dispersal in a temperate forest understory. Proceedings of the National Academy of Sciences USA 101: 76517656. https://doi.org/10.1073/pnas.0400814101

Gravel D., Beaudet M., Messier C., 2008. Partitioning the factors of spatial variation in regeneration density of shade-tolerant tree species. Ecology 89: 2879-2888. https://doi.org/10.1890/07-1596.1

Harms K.E., Condit R., Hubbell S.P., Foster R.B., 2001. Habitat associations of trees and shrubs in a 50-ha neotropical forest plot. Journal of Ecology 89: 947-959. https://doi.org/10.1111/j.1365-2745.2001.00615.x

Heiri C., Wolf A., Rohreb L., Bugmann H., 2009. Forty years of natural dynamics in Swiss beech forests: structure, composition, and the influence of former management. Ecological Applications 19: 1920-1934. https://doi.org/10.1890/08-0516.1

Hiura T., Fujiwara K., 1999. Density-dependence and co-existence of conifer and broad-leaved trees in a Japanese northern mixed forest. Journal of Vegetation Science 10: 843-850. https://doi.org/10.2307/3237309

Hou J., Mi X., Liu C., Ma K., 2004. Spatial patterns and associations in a Quercus-Betula forest in northern China. Journal of Vegetation Science 15: 407-414. https://doi.org/10.1111/j.1654-1103.2004.tb02278.x

Hubbell S.P., 2006. Neutral theory and the evolution of ecological equivalence. Ecology 87: 1387-1398. https:// doi.org/10.1890/0012-9658(2006)87[1387:NTATEO]2 .0.CO;2

Hurtt G.C., Pacala S.W., 1995. The consequences of recruitment limitation: reconciling chance, history and competitive differences between plants. Journal of Theoretical Biology 176: 1-12. https://doi.org/10.1006/ jtbi. 1995.0170

Illian J.B., Penttinen A., Stoyan H., Stoyan D., 2008. Statistical analysis and modelling of spatial point patterns. John Wiley \& Sons, Chichester.

Janík D., Adam D., Hort L., Král K., Šamonil P., Unar P., Vrška T., 2014. Tree spatial patterns of Abies alba and Fagus sylvatica in the Western Carpathians over 30 years. European Journal of Forest Research 133: 10151028. https://doi.org/10.1007/s10342-014-0819-1

Janík D., Král K., Adam D., Hort L., Šamonil P., Unar P., Vrška T., McMahon S., 2016. Tree spatial patterns of Fagus sylvatica expansion over 37 years. Forest Ecology and Management 375: 134-145. https://doi. org/10.1016/j.foreco.2016.05.017

Johnson D.J., Bourg N.A., Howe R., McShea W.J., WolfA., Clay K., 2014. Conspecific negative density-dependent 
mortality and the structure of temperate forests. Ecology 95: 2493-2503. https://doi.org/10.1890/13-2098.1

Jonášová M., Prach K., 2004. Central-European mountain spruce (Picea abies (L.) Karst.) forests: regeneration of tree species after a bark beetle outbreak. Ecological Engineering 23: 15-27. https://doi.org/10.1016/j. ecoleng.2004.06.010

Keren S., Motta R., Govedar Z., Lucic R., Medarevic M., Diaci J., 2014. Comparative structural dynamics of the Janj mixed old-growth mountain forest in Bosnia and Herzegovina: are conifers in a long-term decline? Forests 5: 1243-1266. https://doi.org/10.3390/f5061243

King D.A., Wright S.J., Connell J.H., 2006. The contribution of interspecific variation in maximum tree height to tropical and temperate diversity. Journal of Tropical Ecology 22: 11-24. https://doi.org/10.1017/ S0266467405002774

Klopcic M., Jerina K., Boncina A., 2010. Long-term changes of structure and tree species composition in Dinaric uneven-aged forests: are red deer an important factor? European Journal of Forest Research 129: 277288. https://doi.org/10.1007/s10342-009-0325-z

Kotanen P.M., 2007. Effects of fungal seed pathogens under conspecific and heterospecific trees in a temperate forest. Canadian Journal of Botany 85: 918-925. https:// doi.org/10.1139/B07-088

Koukoulas S., Blackburn G.A., 2005. Spatial relationships between tree species and gap characteristics in broadleaved deciduous woodland. Journal of Vegetation Science 16: 587-596.

Kraft N., Adler P., Godoy O., James E., Fuller S., Levine J.M., 2015. Community assembly, coexistence, and the environmental filtering metaphor. Functional Ecology 29: 592-599. https://doi.org/10.1111/1365-2435.12345

Kuang X., Yuan Z., Lin F., Ye J., Wang X., Wang Y., Hao Z., 2017. Conspecific density dependence and community structure: insights from 11 years of monitoring in an oldgrowth temperate forest in Northeast China. Ecology and Evolution 7: 5191-5200. https://doi.org/10.1002/ ece 3.3050

Kuninaga T., Hirayama K., Sakimoto M., 2015. Negative canopy-understorey interaction shapes the sapling bank of Fagus crenata in a cool-temperate, coniferhardwood mixed forest. Plant Ecology 216: 1191-1202. https://doi.org/10.1007/s11258-015-0501-9

Kunstler G., Falster D., Coomes D.A., Hui F., Kooyman R.M., Laughlin D.C., Poorter L., Vanderwel M., Vieilledent G., Wright S.J., Aiba M., Baraloto C., Caspersen J., Cornelissen J.H.C., Gourlet-Fleury S., Hanewinkel M., Herault B., Kattge J., Kurokawa H., Onoda Y., Peñuelas J., Poorter H., Uriarte M., Richardson S., Ruiz-Benito P., Sun I.-F., Ståhl G., Swenson N.G., Thompson J., Westerlund B., Wirth C., Zavala M.A., Zeng H., Zimmerman J.K., Zimmermann N.E., Westoby M., 2016. Plant functional traits have globally consistent effects on competition. Nature 529: 204-207. https://doi.org/10.1038/nature16476

Laliberté E., Paquette A., Legendre P., Bouchard A., 2009.
Assessing the scale-specific importance of niches and other spatial processes on beta diversity: a case study from a temperate forest. Oecologia 159: 377-388. https://doi.org/10.1007/s00442-008-1214-8

Lasky J.R., Uriarte M., Boukili V.K., Chazdon R.L., 2014. Trait-mediated assembly processes predict successional changes in community diversity of tropical forests. Proceedings of the National Academy of Sciences USA 111: 5616-5621. https://doi.org/10.1073/ pnas. 1319342111

Lieberman M., Lieberman D., 2007. Nearest-neighbor tree species combinations in tropical forest: the role of chance, and some consequences of high diversity. Oikos 116: 377-386. https://doi.org/10.1111/j.2006.00301299.15370.x

Loosmore N.B., Ford E.D., 2006. Statistical inference using the $G$ or $K$ point pattern spatial statistics. Ecology 87: 1925-1931. https://doi.org/10.1890/00129658(2006)87[1925:SIUTGO]2.0.CO;2

Mina M., del Río M., Huber M.O., Thürig E., Rohner B., 2018. The symmetry of competitive interactions in mixed Norway spruce, silver fir and European beech forests. Journal of Vegetation Science 29: 775-787. https://doi.org/10.1111/jvs.12664

Nagel T., Svoboda M., Diaci J., 2006. Regeneration patterns after intermediate wind disturbance in an oldgrowth Fagus-Abies forest in southeastern Slovenia. Forest Ecology and Management 226: 268-278. https:// doi.org/10.1016/j.foreco.2006.01.039

Nagel T.A., Svoboda M., Rugani T., Diaci J., 2010. Gap regeneration and replacement patterns in an old-growth Fagus-Abies forest of Bosnia-Herzegovina. Plant Ecology 208: 307-318. https://doi.org/10.1007/s11258009-9707-z

Nakashizuka T., Kohyama T., 1995. The significance of the asymmetric effect of crowding for coexistence in a mixed temperate forest. Journal of Vegetation Science 6: 509-516. https://doi.org/10.2307/3236349

Orman O., Szewczyk J., 2015. European beech, silver fir, and Norway spruce differ in establishment, height growth, and mortality rates on coarse woody debris and forest floor - a study from a mixed beech forest in the Western Carpathians. Annals of Forest Science 72: 955965. https://doi.org/10.1007/s13595-015-0492-7

Pacala S.W., Levin S.A., 1997. Biologically generated spatial pattern and the coexistence of competing species. In: Tilman D., Kareiva P. (eds.), Spatial ecology: the role of space in population dynamics and interspecific interactions. Princeton University Press, Princeton, pp. 204-232.

Paluch J., Bartkowicz L., Moser W.K., 2019. Interspecific effects between overstorey and regeneration in smallscale mixtures of three late-successional species in the Western Carpathians (southern Poland). European Journal of Forest Research 138: 889-905. https://doi. org/10.1007/s10342-019-01209-y

Paluch J., Gruba P., 2012. Effect of local species composition on topsoil properties in mixed stands 
with silver fir (Abies alba Mill.). Forestry 85: 413-426. https://doi.org/10.1093/forestry/cps040

Paluch J., Kołodziej Z., Skrzyszewski J., Bartkowicz L., Gruba P., 2016. Regeneration patterns of the late-successional Abies alba Mill.: inhibition in monospecific stands and colonization in mixed stands. Annals of Forest Science 73: 1015-1024. https://oi. org/10.1007/s13595-016-0573-2

Paluch J.G., Jastrzębski R., 2013. Natural regeneration of shade-tolerant Abies alba Mill. in gradients of stand species compositions: limitation by seed availability or safe microsites? Forest Ecology and Management 307: 322-332. https://doi.org/10.1016/j.foreco.2013.06.035

Parobeková Z., Pittner J., Kucbel S., Saniga M., Filípek M., Sedmáková D., Vencurik J., Jaloviar P., 2018. Structural diversity in a mixed spruce-fir-beech oldgrowth forest remnant of the Western Carpathians. Forests 9: 379. https://doi.org/10.3390/f9070379

Peters H.A., 2003. Neighbour-regulated mortality: the influence of positive and negative density dependence on tree populations in species-rich tropical forests. Ecology Letters 6: 757-765. https://doi.org/10.1046/ j.1461-0248.2003.00492.x

Petrițan I.C., Commarmot B., Hobi M.L., Petrițan A.M., Bigler C.H., Abrudan I.V., Rigling A., 2015. Structural patterns of beech and silver fir suggest stability and resilience of the virgin forest Sinca in the Southern Carpathians, Romania. Forest Ecology and Management 356: 184-195. https://doi.org/10.1016/j. foreco.2015.07.015

Piao T., Comita L.S., Jin G., Kim J.H., 2013. Density dependence across multiple life stages in a temperate old-growth forest of northeast China. Oecologia 172: 207-217. https://doi.org/10.1007/s00442-012-2481-y

Pommerening A., Grabarnik P., 2019. Individual-based methods in forest ecology and management. Springer, Cham.

Pommerening A., Uria-Diez J., 2017. Do large forest trees tend towards high species mingling? Ecological Informatics 42: 139-147. https://doi.org/10.1016/j. ecoinf.2017.10.009

Poulson T.L., Platt W.J., 1996. Replacement patterns of beech and sugar maple in Warren Woods, Michigan. Ecology 77: 1234-1253. https://doi. org/10.2307/2265592

Pretzsch H., 2014. Canopy space filling and tree crown morphology in mixed-species stands compared with monocultures. Forest Ecology and Management 327: 251-264. https://doi.org/10.1016/j.foreco.2014.04.027

Pretzsch H., Block J., Dieler J., Dong P.H., Kohnle U., Nagel J., Spellmann H., Zingg A., 2010. Comparison between the productivity of pure and mixed stands of Norway spruce and European beech along an ecological gradient. Annals of Forest Science 67: 712. https://doi. org/10.1051/forest/2010037

Pretzsch H., Schutze G., 2016. Effect of tree species mixing on the size structure, density, and yield of forest stands. European Journal of Forest Research 135: 1-22. https://doi.org/10.1007/s10342-015-0913-z

Punchi-Manage R., Wiegand T., Wiegand K., Getzin S., Huth A., Gunatilleke C., Gunatilleke I., 2015. Neighborhood diversity of large trees shows independent species patterns in a mixed dipterocarp forest in Sri Lanka. Ecology 96: 1823-1834. https://doi. org/10.1890/14-1477.1

R Core Team, 2020. R: A language and environment for statistical computing. R Foundation for Statistical Computing, Vienna. https://www.R-project.org/

Rajala T., 2019. Segregation measures for multitype spatial point patterns. R package 'spatialsegregation' v2.45. https://cran.r-project.org/web/packages/ spatialsegregation/spatialsegregation.pdf

Ramage B.S., Mangana I.J., 2017. Conspecific negative density dependence in American beech. Forest Ecosystems 4: 8. https://doi.org/10.1186/s40663-0170094-y

Rayburn A., Wiegand T., 2012. Individual species-area relationships and spatial patterns of species diversity in a Great Basin, semi-arid shrubland. Ecography 35: 341347. https://doi.org/10.1111/j.1600-0587.2011.07058.x

Rothe A., Binkley D., 2001. Nutritional interactions in mixed species forests: a synthesis. Canadian Journal of Forest Research 31: 1855-1870. https://doi.org/10.1139/ x01-120

SAS Institute Inc., 2014. SAS/STAT® 13.2 User's Guide. SAS Institute, Cary.

Schnitzler A., Closset D., Gafta D., Cristea V., Schwoehrer C., 2004. Dynamique des populations et mosaïque forestière en hêtraie-sapinière naturelle préservée. Une comparaison entre Vosges et Carpates. Revue d'Écologie (Terre et Vie) 59: 213-229.

Šebková B., Šamonil P., Valtera M., Adam D., Janík D., 2012. Interaction between tree species populations and windthrow dynamics in natural beech-dominated forest, Czech Republic. Forest Ecology and Management 280: 9-19. https://doi.org/10.1016/j.foreco.2012.05.030

Simon A., Gratzer G., Sieghardt M., 2011. The influence of windthrow microsites on tree regeneration and establishment in an old growth mountain forest. Forest Ecology and Management 262: 1289-1297. https://doi. org/10.1016/j.foreco.2011.06.028

Stăncioiu P.T., O’Hara K.L., 2006. Regeneration growth in different light environments of mixed species, multiaged, mountainous forests of Romania. European Journal of Forest Research 125: 151-162. https://doi. org/10.1007/s10342-005-0069-3

Stoll P., Prati D., 2001. Intraspecific aggregation alters competitive interactions in experimental plant communities. Ecology 82: 319-327. https://doi. org/10.1890/0012-9658(2001)082[0319:IAACII]2.0. $\mathrm{CO} ; 2$

Swamy V., Terborgh J., Dexter K.G., Best B.D., Alvarez P., Cornejo F., 2011. Are all seeds equal? Spatially explicit comparisons of seed fall and sapling recruitment in a 
tropical forest. Ecology Letters 14: 195-201. https://doi. org/10.1111/j.1461-0248.2010.01571.x

Szewczyk J., Szwagrzyk J., 1996. Tree regeneration on rotten wood and on soil in old-growth stand. Plant Ecology 122: 37-46. https://doi.org/10.1007/ BF00052814

Szwagrzyk J., Szewczyk J., Maciejewski Z., 2012. Shade-tolerant tree species from temperate forests differ in their competitive abilities: a case study from Raztocze, south-eastern Poland. Forest Ecology and Management 282: 28-35. https://doi.org/10.1016/j. foreco.2012.06.031

Thelin G., Rosengren U., Callesen I., Ingerslev M., 2002. The nutrient status of Norway spruce in pure and in mixed-species stands. Forest Ecology and Management 160: 115-125. https://doi.org/10.1016/ S0378-1127(01)00464-9

Tsai C.H., Lin Y.C., Wiegand T., Nakazawa T., Su S.H., Hsieh C.H., Ding T.S., 2015. Individual speciesarea relationship of woody plant communities in a heterogeneous subtropical monsoon rainforest. PloS One 10: e0124539. https://doi.org/10.1371/journal. pone. 0124539

Uriarte M., Condit R., Canham C.D., Hubbell S.P., 2004. A spatially explicit model of sapling growth in a tropical forest: does the identity of neighbours matter? Journal of Ecology 92: 348-360. https://doi.org/10.1111/j.00220477.2004.00867.x

Vázquez D.P., Melián C.J., Williams N.M., Blüthgen N., Krasnov B.R., Poulin R., 2007. Species abundance and asymmetric interaction strength in ecological networks. Oikos 116: 1120-1127. https://doi.org/10.1111/j.00301299.2007.15828.x

Volkov I., Banavar J.R., He F., Hubbell S.P., Maritan A., 2005. Density dependence explains tree species abundance and diversity in tropical forests. Nature 438: 658-661. https://doi.org/10.1038/nature04030

Vrška T., Adam D., Hort L., Kolář T., Janík D., 2009. European beech (Fagus sylvatica L.) and silver fir (Abies alba Mill.) rotation in the Carpathians - a developmental cycle or a linear trend induced by man? Forest Ecology and Management 258: 347-356. https:// doi.org/10.1016/j.foreco.2009.03.007

Wagner R.G., Radosevich S.R., 1998. Neighborhood approach for quantifying interspecific competition in coastal Oregon forests. Ecological Applications 8: 779-794. https://doi.org/10.1890/10510761(1998)008[0779:NAFQIC]2.0.CO;2
Wang X., Wiegand T., Hao Z., Li B., Ye J., Lin F., 2010. Species associations in an old-growth temperate forest in north-eastern China. Journal of Ecology 98: 674-686. http://doi.org/10.1111/j.1365-2745.2010.01644.x

Weiner J., 1984. Neighbourhood interference amongst Pinus rigida individuals. Journal of Ecology 72: 183195. https://doi.org/10.1111/j.1365-2745.2010.01644.x

Wiegand T., Gunatilleke C.V.S., Gunatilleke I.A.U.N., Huth A., 2007. How individual species structure diversity in tropical forests. Proceedings of the National Academy of Sciences USA 104: 19029-19033. https:// doi.org/10.1073/pnas.0705621104

Wiegand T., Martinez I., Huth A., 2009. Recruitment in tropical tree species: revealing complex spatial patterns. American Naturalist 174: 106-140. https://doi. org/10.1086/605368

Wiegand T., Moloney K.A., 2014. Handbook of spatial point-pattern analysis in ecology. CRC Press, Boca Raton.

Wills C., Condit R., Foster R.B., Hubbell S.P., 1997. Strong density- and diversity-related effects help to maintain tree species diversity in a neotropical forest. Proceedings of the National Academy of Sciences USA 94: 1252-1257. https://doi.org/10.1073/pnas.94.4.1252

Wilson J.B., 2011. The twelve theories of co-existence in plant communities: the doubtful, the important and the unexplored. Journal of Vegetation Science 22: 184-195. https://doi.org/10.1111/j.1654-1103.2010.01226.x

Woods K.D., 1979. Reciprocal replacement and the maintenance of codominance in a beech-maple forest. Oikos 33: 31-39. https://doi.org/10.2307/3544508

Woods K.D., 1984. Patterns of tree replacement: canopy effects on understory pattern in hemlock-northern hardwood forests. Vegetatio 56: 87-107. https://doi. org/10.1007/BF00033051

Wright S.J., 2002. Plant diversity in tropical forests: a review of mechanisms of species coexistence. Oecologia 130: 1-14. https://doi.org/10.1007/s004420100809

Zhang C., Zhao X., Gadow K., 2010. Partitioning temperate plant community structure at different scales. Acta Oecologica 36: 306-313. https://doi.org/10.1016/j. actao.2010.02.003

Zhou Q., Shi H., Shu X., Xie F., Zhang K., Zhang Q., Dang H., 2019. Spatial distribution and interspecific associations in a deciduous broad-leaved forest in north-central China. Journal of Vegetation Science 30: 1153-1163. https://doi.org/10.1111/jvs.12805 